\title{
Diaspora as a Communicating Actor in Public Diplomacy Compared to Public Government Diplomacy in the Case of Kosovo
}

\author{
Resul Sinani \\ Albanian / University for Business and Technology, Kosova \\ resul.sinani@ubt-uni.net
}

\section{Doi:10.5901/ajis.2015.v4n2p269}

Abstract

During the past two decades Kosovo has often been a subject of the news, and taken airtime in the most powerful international media through which it became known to the world public opinion. The highest presence was during the 1998-1999 war and especially during the period of the NATO bombing campaign against Serbia when almost everything was broadcast live. This picture of Kosovo still prevails in the world's public opinion and it identifies Kosovo with the war, thus as a post-conflict society. Ever since the proclamation of independence of $17^{\text {th }}$ of February 2008 its governments have tried to change and improve this image through public diplomacy, but despite these attempts the tone of the stories in the world media, which as we know is more attracted to negative than to positive news, especially when it comes to small countries like Kosovo has not changed. This article deals with the attempts of the public diplomacy of Kosovo and the news it has produced during 2014-2015 for the international media and the world public compared to the news and the image that was projected by the members of Kosovar diaspora for the world opinion. These arguments that the potential of the diaspora is many times greater while the image is completely positive when compared to the potential and the image that comes from within Kosovo, which is completely negative.

Keywords: Image, public diplomacy, Diaspora, Kosovo, world opinion, international media.

\section{Introduction}

Kosovo is the youngest country on the European continent. Its image is still being connected with the war of 1999 while ever since then the news that comes out of Kosovo speak of various incidents and based upon those the image of Kosovo is still the one of the post-conflict country. This image is completely opposite when compared with the reality, because with all the difficulties in building a stable and democratic society Kosovo has institutions which have proven they can function normally and in a stable manner.

The image of Kosovo in something that the country's institutions have been preoccupied with, but it is also a preoccupation of its citizens who would want this image to be positive. For this reason the Ministry of Foreign affairs of the Republic of Kosovo in cooperation with several organizations from the civil society, including the artistic community, has taken initiatives and organized various activities in different countries of the EU, but also in other parts of the world in order to present the reality, which is completely opposite from the image that the citizens of those countries have about Kosovo, an image they continue to connect with the war of 1999. Unfortunately small countries like Kosovo become a part of the world media only for bad news, and these have not been missing during the post war years and they continue to keep and cultivate the image of Kosovo as an unstable country. Among the bad news that come out of Kosovo and grab the attention of the international media are the stories that deal with corruption within the country, political instability, violent protests, inter-ethnic incidents, limited freedom of expression etc. which seldom leave room for positive and mainly individual news stories like the victories of Majlinda Kelmendi in European and World Judo championships.

Kosovar citizens are happy with any positive news about their country which are mainly connected with the success of our compatriots in the western world. The singer Rita Ora or the football players representing Switzerland like Xherdan Shaqiri, Valon Behrami, Granit Xhaka etc. or the boxer Haxhi Krasniqi, are valued as pride of the nation and positive images of Kosovo in the world. Their successes are met with a lot of emotion by the Kosovars who keep them as a reference point whenever they leave the country.

This article which treats the image of Kosovo in the world is using analyses as a methodology, since in analyses and places against each other the images which come out of Kosovo and those that come from the Kosovar diaspora. It shows that the images coming out of Kosovo are mainly negative while whose coming from the Kosovars in diaspora are 
mainly positive (despite the fact that there are enough negative cases coming from the diaspora, like the incidents that have to do with family violence or drug trafficking). It also shows that there is no coordination or cooperation between the Kosovar institutions and the successful Kosovars of diaspora, cooperation which if coordinated would have a large impact on improving the image of Kosovo in the world. Therefore it is recommended that this potential of the diaspora would be the best used for such a purpose.

The objective if the article is proving that institutions of a small country like Kosovo whatever they may be have difficulties on reaching successes in public diplomacy and improving the countries image. At the same time people with their origins in these places, concretely Kosovo, can be extremely popular in the international arena, therefore if there is a cooperation agreement with these personalities - then public diplomacy will be much more efficient - thus directly influencing the improvement of a country's image.

\section{Literature Review}

One description of public diplomacy, in one of its brochures The Center for Public Diplomacy Eduard R. Murrow, says that "The public diplomacy... deals with the influence of public attitudes in forming and executing foreign policies. It includes dimensions of international relations beyond international diplomacy: government cultivating of public opinion in other countries, cooperation of various groups and private interests of a country with those of another; reporting of foreign affairs and their influence of politics; communicating through those whose work is communication as well as between the diplomats and the foreign correspondents as well as inter-cultural processes"1 therefore of public diplomacy but the number of actors is much wider. It is understandable that the concept and the actors of public diplomacy have changed and adapted with the circumstances of the time during the years. Today, with the new media, especially those on the internet all accountability is done differently. Therefore, as Bruce Gregory says that today, by public diplomacy we understand the instrument used by the states, the societies of states and some inter-governmental and non-governmental actors in order to understand the culture, stances and attitudes in order to create and manage relationships and influence opinions as well as mobilize actions in order to forward their interests and values (Gregory, 2011). In the meantime the new media have given great opportunities for smaller countries who wish to develop public diplomacy. Nichollas Cull gives several factors which create what is being called the new public diplomacy. Since the bipolar clash has stopped and the world is more open. Because the public diplomacy is not a monopoly of states and actors in communication have been added, like the regional organizations, EU, NGO-s, interest groups, corporations (including the international broadcasters) as well as non-government actors; the end of the cold war happened at the same time when the new communication technologies allowing global communication in real time appeared; there is a new direction in public diplomacy. The heads of states speak on their byrocratic transmissions and they reach the entire world. People have more information to choose from than ever before. Public diplomacy now cannot be seen as something addressed to only one audience, but it is being addressed to individuals one by one and the government has to make the process easier; there are new challenges. The increase of the speed of communication makes the message travel from one side of the world to the other, at the time when they are asleep and this presents a barrier between inside and outside information; there is a new terminology of public diplomacy for prestige and international image, today we speak of the ever present terminology of Nye, soft power and breeding where values and culture have an integral role (Cull, 2012. Pg. XII). The concept of soft power was created and developed by Harvard professor, Joseph s. Nye Jr. (1990). He starts at 1990 and comes back and develops it further in the study of 2002 while he gives it final shape in 2004. According to Nye soft power of a country comes from the culture of the country, it's values and foreign policies (Nye, 2004. pg 11). Today, public diplomacy, as Jan Melissen (2005) states, is the key instrument of the soft power.

\section{Public Diplomacy Versus Kosovo's Image in the World}

Kosovar diplomacy is young, inexperienced and it is still not consolidated enough. Today Kosovo has 23 embassies ${ }^{2}$ all over the world and they are mainly small embassy with not enough funds to develop diplomatic activities. Therefore in 2011 The Ministry of Foreign Affairs of the Republic of Kosovo signed an agreement with the British Embassy in Prishtina and the British Council in Kosovo which had a purpose of advancing public diplomacy of Kosovo called "Communicating

1 http://fletcher.tufts.edu/Murrow/Diplomacy

2 http://www.mfa-ks.net/?page=1,49 
with Europe through public diplomacy"3. A similar agreement was signed with the Kosovar Fund for Open society (KFOS) ${ }^{4}$. Thanks to these agreements during the past years hundreds of activities were developed, like visits to different EU countries where meetings with politicians, diplomats and members of the civil society or the media were organized. Also, expositions were organized as well as media editorials and support was given to the cultural activities of Kosovar artists in the countries that have not recognized the Kosovar independence. In fact this was the main goal of public diplomacy of Kosovo, which was said by the Minister Enver Hoxhaj when the agreement was signed - he said "this project is attempting to include advocating, informational activities as well as creating powerful channels with explanatory character, known personalities of public life, civil society of the media and intellectuals, who will have a chance to help the ministry of foreign Affairs and the Kosovar Government in representing, presenting and promoting our national interest in the concrete field of rising the number of recognitions" 5 . But, beyond this attempt to rise the number of recognitions Kosovo needs public diplomacy in order to improve its image in the world. The bad image of Kosovo in the world is the main preoccupation and has been a point of discussion for years within Kosovo. In his editorial, entitled "the politics of images" the editor in chief of Koha Ditore Agron Bajrami while concluding that Kosovo has a negative image in the world says that:

"This reputation was created by dozens of critical reports which have often very precisely identified the acute problems of our country, from the failed governing policies and electoral manipulations up to criminal actions and economic theft. There reports have built a heavy image of Kosovo, where the main negative characters are mainly the same characters who, even today, lead the country. Reports made by NATO, EU, OSCE the UN and many NGO-s have built an image of an insecure, intolerant, un-democratic Kosovo which has a corrupted political class and a system which is slowly but certainly transforming itself into an economic oligarchy."6

So despite the activities of the public diplomacy, which were done in the past few years the image of Kosovo, even today, is not the one that is desired. And the main culprits for this are within the country so things that happen inside Kosovo. In a statement given to Radio Free Europe Shpend Kursani from the Kosovar Institute for Research and Policies Development - KIPRED, estimates that since the proclamation of independence the Serbian diplomacy, or counterdiplomacy has been very harsh towards Kosovo but also quite effective in damaging its image. But he adds that Kosovars themselves have also done damage to that image.

"As well as Serbia damaging Kosovar image with its diplomacy, we, within the country have not lacked far behind Serbia since we continuously managed to prove that we are not capable of fighting organized crime - a thing for which Kosovo is best known in the international arena. The steps we have taken have mainly been cosmetic steps- made to improve the image instead of substantial steps - which would have actually improved the said image"7.

This image, especially during 2014 and the start of 2015, because of developments within the country have not managed to improve, but it has continued being dark and negative which can be illustrated with the main political developments which have generally been negative. An attempt to improve the branding and image of Kosovo in the world was made through the Kosovo Young Europeans ${ }^{8}$ campaign. This campaign's base was a publicity video which was broadcast on the international media like the CNN and the BBC. But it seems that the influence of the video was not what was unexpected when put against the news these media were giving from Kosovo- which were generally negative. Furthermore it seems that the effect of the video was bigger inside Kosovo than abroad.

\section{The Images of the Main Developments during 2014 - 2015 that Were Sent Out of Kosovo}

The developments and events that have attracted the international public and media attention have generally been negative, with several exemptions which have given positive images and they were mainly from the field of sports. In this chapter we take into consideration the main events which had the most impact.

\footnotetext{
${ }^{3} \mathrm{http}: / / w w w . m f a-k s . n e t /$ page $=1,128$

${ }^{4}$ http://www.mfa-ks.net/?page=1,4,1064

${ }^{5} \mathrm{http}: / /$ www.mfa-ks.net/?page=1,128

${ }^{6} \mathrm{http}: / / \mathrm{koha} \cdot \mathrm{net} / \mathrm{?}$ id $=31 \& 0=511$

${ }^{7}$ http://www.evropaelire.org/content/article/24975000.html

${ }^{8} \mathrm{http}: / /$ www.kosovo-young.com/
} 
Among many events and developments which have marked the period 2014-2015,as negative events for Kosovo's image were:

a) The over-stretched process of forming institutions after the elections of $8^{\text {th }}$ of June 2014,

b) Kosovar's participation in ISIS,

c) Violent protests of $24^{\text {th }}$ and $27^{\text {th }}$ of January 2015 ,

d) The exodus of the Kosovars towards the Western European countries.

While as positive events for the Kosovo's image in the world we chose:

e) General elections of the $8^{\text {th }}$ of June 2014,

f) Friendly football matches of the Kosovar representation,

g) Medal victories by the Judoist Majlinda Kelmendi.

\subsection{The over-stretched process of forming institutions}

The general elections for the Kosovar parliament were held of the $8^{\text {th }}$ of June 2014. They were valued as regular and the results were accepted by all the political parties. The elections were won by the Democratic Party of Kosovo for the third time in a raw. But two days after the elections three opposition parties, Kosovar Democratic Alliance, The Alliance for the future of Kosovo and NISMA for Kosovo, signed an agreement on post-election coalition which had a purpose of making it impossible for the Kosovar Democratic Party (PDK), which had lead the government through two previous terms to form a government, by stating that "There will not be a Thaçi 3 government". After this, a long political and legal battle went on, where the opinion of the constitutional Court was required twice. First time the president asked explanations about the nomination for the PM, secondly PDK, since it believed that Isa Mustafa was chosen irregularly as the head of the parliament.

"We believe that there have been constitutional as well as procedural breaches and we ask for this procedure to be suspended and start a new seance. We have asked for this procedure to be suspended and the Constitutional court can decide on this" - declared the PDK parliament member Xhavit Haliti, in whose name the case was sent to the Constitutional court.

After about five months of the "political cramp" during which the government functioned only to fulfill its basic functions, during a public forum the US ambassador in Kosovo, sends a harsh criticism towards the political leaders who could not agree on forming a government. ON $6^{\text {th }}$ of November, during a debate organized by the movement FOL, ambassador, Tracey Ann Jacobson, asked about the role of the international factor and the possibility of its involvement with advising Kosovar politicians on finding a solution for the knot which had paralyzed the institutions of the country, she did not hesitate of telling them bluntly what had to be said: "there is a message that I have given to all the leaders and I can even say it in Albanian: Do not fuck it up!"10. Shortly after this statement on 19th of November 2014, in the office of the president and in the presence of the American Ambassador an agreement for forming a coalition between PDK and LDK was reached.

"Both political leaders have confirmed their devotion to quick foreclosure of the institution building process on the basis of the constitution, the constitutional court and the constitutional principles that preserve the multi-ethnic character of the Republic of Kosovo, fulfill the international obligations of law and order and strengthening the euro-Atlantic road of our country"11 - states the media declaration of president Jahjaga.

This agreement paved the way for creating the new institutions after the $8^{\text {th }}$ of June elections. On the $9^{\text {th }}$ of November, Isa Mustafa was chosen as the Prime Minister of the Kosovar government, after the general elections he was criticized and created a negative image for the political class and the country in general.

\subsection{Kosovar's participation in ISIS}

The social media images of the Kosovar Lavdrim Muhaxhiri decapitating a hostage have terrified the Kosovar as well as

${ }^{9} \mathrm{http}: / /$ koha. $n e t / ? i d=27 \& /=13599$

$10 \mathrm{http}: / /$ koha. $n$ et/?id=27\&/=32223

${ }^{11}$ http://www.dw.de/n\%C3\%AB-kosov\%C3\%AB-pdk-dhe-ldk-arrijn\%C3\%AB-marr\%C3\%ABveshje-koalicioni/a-18074914 
international public. The media report that about 185 Kosovars have been recruited and have joined the ranks of ISIS fighters ${ }^{12}$. This has been seen as negative image for the country. Reports of the deeds of this ISIS member have been transmitted on most of the world media. In the meantime, the Kosovar Police ${ }^{13}$ during one operation arrested 40 individuals in 60 raids who have been accused of taking part in the fighting in Syria and Iraq. These individuals, according to the police and the State prosecutor were suspected of joining organizations like ISIS and AL Nousra. According to the police the arrested were suspected of committing a crime against the constitutional order of the Republic of Kosovo, an act which is punishable by the Penal Code. In the meantime even the Minister of Foreign Affairs, Hashim Thaçi spoke of the danger that ISIS presents not only for Kosovo but for the entire region:

"The EU should not delay the process of admissions, expanding and integrating Kosovo, and the region in the EU and NATO. Every delay in this process is dangerous. It opens up the way for interference and increased influence of Russia in the Balkans, as for the political, economic and military aspect. This delay has also opened up the way for ISIS to penetrate the region and expand its influence in the Balkans." - said the Kosovar foreign Minister."14

\subsection{The violent protests of the $24^{\text {th }}$ and the $27^{\text {th }}$ of January 2015}

An attempt to visit a church, made by a group of Serbs who have come from Serbia to Gjakova for the orthodox Christmas was stopped by a group of the society "the calls of mothers" - a society of the families whose family members are missing since the war of 1999. On this occasion, the minister for returns and communities of the Kosovar government, who is an ethnic Serb, Aleksandar Jablanovic, offended the mothers of the missing. He stated:

"This is a great and holy celebration. The savages who have stopped the Serbs from coming to their torched homes will not serve anyone. We will ask for explanations by the interior minister on how this happened."15

This statement, together with the law for public enterprises which was connected to the faith of the metallurgy giant of Kosovo "Trepça", have made the opposition and the civil society get out and protest. The first protest was on the $24^{\text {th }}$ of January and the protests have escalated into violence when the Kosovar government building was damaged. After this protest there were many reactions saying that violent protests like those are damaging the image of Kosovo in the entire world.

"The right to gather peacefully and join compatriots voluntarily to demonstrate is essential for a functioning democracy. But violence during protests is illegal and unacceptable. For this reason we condemn the acts of violence by a group of protesters of the principles of the freedom of media"16 - says in the joint statement of the QUINT countries that was published by the German Embassy in Prishtina.

While the protest of the $27^{\text {th }}$ of January happened to be even more violent, about 170 individuals were hurt, 107 of whom were police officers, 53 protesters and 10 were ordinary citizens. These protests were valued as bad image for Kosovo which was transmitted abroad. The minister of the Interior Affairs, Skënder Hyseni, the day after the protests, among other things said:

"Everyone should know that in Kosovo there is law and order for everyone, based on the Kosovar constitution which is the spine of a country, in which the police is the key instrument for the security of the country. The citizens are free to protest, but no one should set the agenda for the police or the institutions of law and order. Images like these have badly damaged the Kosovar image in the world."17

\footnotetext{
12 http://botasot.info/lajme/386392/rreth-195-persona-nga-kosova-kane-shkuar-ne-siri/

${ }_{13} \mathrm{http}$ ://www.evropaelire.org/content/article/26524328.html

14 http://www.kohajone.com/index.php/kosove/thaci-ballkani-po-rrezikohet-nga-rusia-e-isis

15 http://www.telegrafi.com/lajme/jabllanoviqi-i-quan-egersira-protestuesit-ne-gjakove-video-2-56413.html

16 http://www.dw.de/reagime-t\%C3\%AB-quint-p\%C3\%ABr-dhun\%C3\%ABn-n\%C3\%AB-protestat-e-dit\%C3\%ABs-s\%C3\%AB-shtun\%C3 $\%$ AB/a-18216090

17 http://infoglobi.com/hyseni-me-protesten-e-djeshme-u-demtua-imazhi-i-kosove/ 


\subsection{The exodus of Kosovars to the EU countries}

The end of 2014 and especially the beginning of 2015 has been marked by a wave of illegal emigration towards the EU countries. Thousands of people went to escape from Kosovo by illegally crossing the border between Serbia and Hungary. There are no exact numbers for those that have left but it is an estimated 100 thousand, and there are even higher estimates $f$ the numbers of people who have ended up pin Austria, France, mainly Germany and other EU countries through Hungary. This phenomena, has troubled the public opinion inside as well as outside of Kosovo while the reasons for the migration are thought to be many. In the analyses called "which Kosovar citizens are more prone to migrate to the EU countries?" which was made and published by the Group for the political and judicial studies of Kosovo it says that "the individuals who have no knowledge about the immigration policies of the EU are mostly interested in migrating. According to this research corruption, the existence of organized crime, non-functioning of the legal state and the high levels of unemployment are the main reasons why the Kosovars want to migrate abroad.

"All of these factors make the migration in Kosovo to not be seen only as a phenomenon connected with the desire of Kosovar citizens to get outside of its borders and settle in the countries of the Schengen zone, or other EU countries but it is a phenomenon which is mainly generated by the factors which are inside the country." 18 - stated Dren Doli, of this institute

The tempo of emigration has slowed down recently but the images portraying the columns of immigrants crossing the border illegally in low temperatures and harsh conditions, which were transmitted through the main European Media, gave a very negative image of Kosovo.

\subsection{Kosovar General elections of the $8^{\text {th }}$ of June}

Among the positive developments which influenced the improvement of Kosovo's image in the world there is the process of general elections of the $8^{\text {th }}$ of June. After the accusations about the 2010 elections, which were made about massive voting manipulations, these elections were seen as an important step for the country. The general elections were marked as orderly and according to the international standards. The EU mission for observing the Kosovar elections evaluated them positively. In this mission report says:

"The premature elections of the 8th of June 2014 for the Kosovar parliament with 120 seats are the second general elections held after the proclamation of independence in 2008, and the first general elections held in Kosovo according to Kosovar laws, after the Brussels agreement on normalizing the relations between Belgrade and Prishtina. The elections were transparent and they have consolidated the progress made during the local elections of 2013. The legal framework which has regulated the previous local and general elections has remained in power for these elections too. In accordance with the constitution the system of the reserved seats for political subjects representing the minority communities, which has been used as a temporary measure during the two previous Parliaments, has been replaced with the system of granting 20 guaranteed seats. Despite number of attempts to reform the Kosovar election system the flaws identified during the previous elections have not been fixed. Despite that the legislation offers enough bases for democratic elections in accordance with the international instruments for which Kosovo has pledged in its constitution."19

\subsection{Friendly matches of the Kosovar football representation}

On the $5^{\text {th }}$ of march 2014, for the first time in history, the Kosovar representation in Football played a friendly game. In the stadium Adem Jashari in Mitrovica the Kosovar representation met Haiti. This became possible after FIFA green lighted Kosovo for friendly matches. The game got the interest of the world sporting opinion and this successful organization was valued highly by FIFA and various sporting media. In its report on the game BBC, besides the game itself, also wrote about the history of the past years in Kosovo stating that the best players with Kosovar origins are representing Switzerland. ${ }^{20}$ This historic game ended with a 0-0 score and the Kosovars were happy with the fact that now the door for international competitions was opened. In the meantime the Kosovar representation played three more matches, with

${ }^{18}$ http://www.telegrafi.com/lajme/faktoret-e-shumte-pse-kosovaret-synojne-migrimin-2-34816.html $19 \mathrm{http}$ ://eeas.europa.eu/eueom/missions/2014/kosovo/pdf/eu-eom-kosovo-2014-final-report_sq.pdf 20 http://www.bbc.com/news/world-europe-26451936 
Turkey, Senegal and Oman, and each of them attracted the attention of the international media managing to transmit a positive image of Kosovo abroad.

\subsection{Judo- ist Majlinda Kelmendi double champion of the world}

During 2013 the Judo-ist Majlinda Kelmendi, reached a historic success for the country. On the world championship for seniors, held in Rio de Janeiro in Brasil she got the first place and was awarded the golden medal in the category of up to $53 \mathrm{~kg}$. In the finals she beat the Brazilian Judo-ist, Erika Miranda. "I dedicate this success to Kosovo, my coach and my family as well as all Albanians", declared Majlinda Kelmendi for "Koha Ditore", a short while after she was pronounced the champion of the world. She has presented an image to the world of a Kosovar sportswoman who, despite the harsh conditions and isolation manages to achieve high levels and gain historic successes in the international arena. ${ }^{21}$ Majlinda repeated the same success in 2014, by defending the title during a championship held in Russia. On this occasion, during the welcoming that was organized in Prishtina, the Minister of Sports, Memli Krasniqi, said that she is an image and an inspiration for Kosovo:

"Majlinda is the face of our country and she is a model to all of us, showing how we can achieve things, how to work for success and a society of values, success and pride."22 - stated Krasniqi.

The image of Majinda Kelmendi, might e the best that Kosovo has managed to send out to the world ever since the end of the war and the proclamation of independence, not only in sports but in general.

\section{The Image of the Kosovar Diaspora during 2014 - 2015}

Kosovo has a large Diaspora in the countries of the Western Europe and the USA. The history of the Kosovar Diaspora is long, but it became much more massive during the 1990-s, during the time of the Milosevic regime when all the Kosovar Albanians were fired from their jobs and were massively prosecuted y the Serbian police state. Although there is no exact number of the Kosovars living in Diaspora it is generally believed that there are over $700000^{23}$ Kosovars, while there are those who believe that the Kosovar Diaspora goes over 1 million. During the 1990-s the image of this Diaspora has been negative because the Kosovars were connected to criminal activities of various types, like stealing and drug trafficking. But during the last decade this image has changed fundamentally, because a new generation of Kosovars is growing up out there, who were born in other countries or who have left while very young and have managed to integrate within their respective societies. There are countless examples of former Kosovar immigrants who have managed to build strong businesses, have finished or are going to prestigious universities, have gotten integrated in the cultural and political life and the societies of the countries they live in. Many are those who have managed to become an example, and an image, not just for the community they represent but also for their country of origin Kosovo, thus becoming the pride of all Albanians.

There are many examples of successful Albanians in various countries of the world, but we will speak only of those whose origins are in Kosovo. In this article we will present only two of them, those who have reached the height of their success during the past two years: a) Footballers with Kosovar origins that plays for the Swiss national team, b) The singer of Kosovar origin, Rita Ora.

\subsection{Footballers with Kosovar origins that plays for the Swiss national team}

There are many football players in the Swiss national team who have Albanian origins. During the world championship Brazil 201424, out of 23 players 5 were of Albanian and 3 were of Kosovar origin. This does not include other players with Albanian origins who have played during qualifying and friendly matches. This fact made the international media attracted to the Kosovar footballers, especially since there were other Albanian players in other teams, like Adnan Jonuzaj who plays for Belgium or Shkodran Mustafi with Germany, which became the world champion. For the needs of this article we

${ }_{21}$ Here are some articles for Majlinda Kelmendi http://www.bbc.co.uk/search?q=majlinda\%20kelmendi ${ }_{22}$ http://koha.net/?id=6\&l=23550

${ }_{23}$ http://www.evropaelire.org/content/article/24716659.html

${ }^{24}$ http://www.telegraph.co.uk/sport/football/teams/switzerland/10810381/Switzerland-World-Cup-2014-squad.html 
will take into consideration only one of these players, who was also one of the stars of the world championship, Xherdan Shaqiri.

Xherdan Shaqiir is a star of the Swiss national football team. He was born in Kosovo in 1991 while when he was 1 years old his parents immigrated to Switzerland. During his career he has achieved a lot of successes. With the team Basel of Switzerland he won the Swiss championship three times in the seasons 2009-10, 2010-11 and 2011-12, while with Bayern Munich he got 8 trophies among which we will mention two Bundesliga, 2012-13 and 2013-14, and above all the UEFA Champions League 2012-13. He is now playing for the Italian club. What is of interest to us is the fact that Shaqiri, through his success has managed to get his homeland and his nation mentioned. He has drawn three flags on his sporting shoes, the flags of Kosovo, Albania and Switzerland and this did not go unnoticed. Also remembered is his celebration after the victory in UEFA Champions League, when he celebrated with two flags: Swiss and Kosovar. Also there are many interviews and reports in various media who speak of his story and they all mention Kosovo. During his last interview on the American network $\mathrm{CNN}^{25}$, Xherdan Shaqiri, besides his successes speaks also of the possibility that in the future he might play for the Kosovar national team. In this long article there is emphasis on his great successes, among which there is the World Championship in Brazil together with two other Kosovars in the Swiss representation, Valon Behrami and Granit Xhaka, as well as the petition that he together with these two players signed asking FIFA to officially recognize the Kosovo representation and allow it to take part in international competitions. The appearances of Xherdan Shaqiri and other Kosovar footballers in the international media as well as the countless articles about them present an excellent example of public diplomacy through sporting activities while greatly contributing in improving the image of Kosovo and Kosovars in the world.

\subsection{Rita Ora}

There is no doubt that the Kosovar who is most famous and mostly appreciated in the world for her art is Rita Ora. She quickly reached the top of the world show biz, and if we concentrate on just the two last years she has achieved unimaginable successes that were never reached by a Kosovar Albanian. A wonderful tale of her journey is made in the last article which was published about her by the Mirror of London, where Rita Ora moved as a refugee together with her family. An article entitled, Rita Ora's journey from refugee to the Voice to Fifty Shades of Grey ${ }^{26}$, speaks of her journey from a refugee, when she was 1 year old to a world superstar. Some of the quotes from the article are:

"...To e Rita Ora is exhausting. Only during the past 12 months Rita has traveled 130 thousand miles around the globe, being busy with TV shows, photo sessions, recordings and even red carpet appearances...

... Saturday night marks the final night of "The Voice" in Britain and ever since September, when Rita sat in the judge seat, which has previously been the seat of Kylie Minogue, the 24 year old has been the undisputed star of the show. The arrival of Rita in "The Voice UK" marked a powerful return of the audiences taking over even the most watched programs in Britain. Last week's edition had 6.3 million viewers, 400 thousand more than last years. All of these The Mirror attributes to what it calls "the Rita effect"..."27

Further on in this article on the life of this talented artist with Albanian roots the British paper Mirror mentioned the fact that after the launch of her debut album "No 1", she toured Asia to launch her clothing line, performed in Moscow, Istanbul, LA, New York. She has also sang for the American President Barack Obama and during the Oscars and Grammy ceremonies, where she was also nominated. "Among the offers for prestigious brands, TV roles etc which Rita receives every week she has the privilege to decide which to take and which to refuse", notes the Mirror. "The hardships of Kosovo are 2 decades a 1.600 miles away, writes Mirror, but metaphorically speaking this is the galactic space that should be traveled to reach Rita Ora" - ends the article of this daily. This and countless other articles that speak of Rita Ora always write about her Albanian Origins and her birthplace, Kosovo. There is no doubt that Rita Ora is the best and most valued image that has ever come out of Kosovo to the world.

25 http://edition.cnn.com/2015/04/02/football/xherdan-shaqiri-inter-milan-switzerland-kosovo

${ }^{26}$ http://www.mirror.co.uk/3am/celebrity-news/rita-oras-journey-refugee-voice-5455641

${ }^{27}$ http://www.mirror.co.uk/3am/celebrity-news/rita-oras-journey-refugee-voice-5455641 


\section{Discusion}

As this article arguments and proves Kosovo, as the youngest country in Europe which is still not a part of the UN and many other international political and non-political bodies, 15 years after the end of the 1999 war and 7 years after the proclamation of independence in 2008 still does not have a positive image in the international scene . Government institutions are aware of the bad image, and they have undertaken some modest attempts to improve it through media campaigns and other forms of public diplomacy. But despite these attempts, despite the media and cultural marketing the images which follow political actions and which appear in the international media are mainly negative. Unlike these images are the examples of Kosovars living in the western European countries, as is the case with sportsman and artists which have become famous not only in the countries in which they live but all over the world. The artist Rita Ora is a typical and the most representative example but there are many other examples too. By looking at the Governments attempts for public diplomacy, and the public diplomacy that is being done by these personalities without even making and effort then the attempts of the government seem modest and inefficient. At the same time if there was a coordinated effort with these personalities then their potential would be many times greater and, as the effect of the cooperation, the image of Kosovo in the world would be much improved .One of these ways to achieve something would be organizing media events which would gather all of these personalities, or declaring the honorable ambassadors of Kosovo in the countries in which they live. But the initiative for something like this would have to come from the government institutions, which with all their attempts can never create a Rita Ora, or Xherdan Shaqiri!

\section{Conclusion}

Public diplomacy of the Kosovar Institutions, with all of its desire and commitment will have difficulties in achieving the desired success in improving image of country in the world. Among others the events that happen within the country, and which continue to attract the attention of the world media are mainly the negative ones which keep showing Kosovo as a place with fragile unstable institutions and as a country which has just got out of the war, although there have been more than 15 years since it ended. A great potential which would help in improving the image of Kosovo in the world is the Diaspora in the countries of the Western Europe and the USA. Up to now the cases of successful Kosovars have managed to achieve more results on this issue than the entire Kosovar public diplomacy. Therefore cooperation and coordination of activities with them should have a much higher impact force and would influence the image of Kosovo and Kosovars in the world in a positive manner.

\section{References}

Bruce Gregory. American Public Diplomacy: Enduring Characteristics, Elusive Transformation. The Hague Journal of Diplomacy 6.3/4 (2011): 351-372.

Jan Melissen. New Public diplomacy: soft power in international relation. Palgrave Macmillian, 2004.

Joseph S. Nye Jr. Soft Power: The Means to Success in World Politics. New york. Public Affairs. 2004.

Joseph S. Nye Jr. The Paradox of American Power: Why the World's Only Superpower Can't Go it Alone. Oxford University Press 2002.

Joseph S. Nye. Jr. Bound to Lead: The Changing Nature of American Power. Basic Books. 1990.

Nicholas J. Cull. The Decline and Fall of the United States Information Agency. Palgrave Macmillan Series in Global Public Diplomacy. 2012.

http://fletcher.tufts.edu/Murrow/Diplomacy

http://www.mfa-ks.net/?page $=1,49$

http://www.mfa-ks.net/?page=1,128

http://www.mfa-ks.net/?page=1,4,1064

http://www.mfa-ks.net/?page=1,128

http://koha. net/?id=31\&0=511

http://www.evropaelire.org/content/article/24975000.html

http://www.kosovo-young.com/

http://koha.net/?id=27\&l=13599

http://koha.net/?id=27\&l=32223

http://www.dw.de/n\%C3\%AB-kosov\%C3\%AB-pdk-dhe-Idk-arrijn\%C3\%AB-marr\%C3\%ABveshje-koalicioni/a-18074914

http://botasot.info/lajme/386392/rreth-195-persona-nga-kosova-kane-shkuar-ne-siri/

http://www.evropaelire.org/content/article/26524328.html

http://www.kohajone.com/index.php/kosove/thaci-ballkani-po-rrezikohet-nga-rusia-e-isis

http://www.telegrafi.com/lajme/jabllanoviqi-i-quan-egersira-protestuesit-ne-gjakove-video-2-56413.html 
http://www.dw.de/reagime-t\%C3\%AB-quint-p\%C3\%ABr-dhun\%C3\%ABn-n\%C3\%AB-protestat-e-dit\%C3\%ABs-s\%C3\%ABshtun\%C3\%AB/a-18216090

http://infoglobi.com/hyseni-me-protesten-e-djeshme-u-demtua-imazhi-i-kosove/

http://www.telegrafi.com/lajme/faktoret-e-shumte-pse-kosovaret-synojne-migrimin-2-34816.html http://eeas.europa.eu/eueom/missions/2014/kosovo/pdf/eu-eom-kosovo-2014-final-report_sq.pdf http://www.bbc.com/news/world-europe-26451936

Some articles for Majlinda Kelmendi http://www.bbc.co.uk/search?q=majlinda\%20kelmendi http://koha.net/?id=6\&l=23550

http://www.evropaelire.org/content/article/24716659.html

http://www.telegraph.co.uk/sport/football/teams/switzerland/10810381/Switzerland-World-Cup-2014-squad.html http://edition.cnn.com/2015/04/02/football/xherdan-shaqiri-inter-milan-switzerland-kosovo http://www.mirror.co.uk/3am/celebrity-news/rita-oras-journey-refugee-voice-5455641 